Научная статья

УДК 304/9

DOI 10.18101/2306-630X-2020-2-41-56

\title{
ХРИСТИАНСКИЙ СОЦИАЛИЗМ КАК ОТРАЖЕНИЕ ДОКТРИНЫ СОЦИАЛЬНОГО ХРИСТИАНСТВА (ЧАСТЬ I)
}

\author{
(C) Сулейманов Тимур Фуатович \\ кандидат философских наук, доцент, \\ руководитель отдела канонизации \\ и увековечивания памяти новомучеников и исповедников, \\ Уфимская епархия Башкортостанской митрополии РПЦ МП \\ Россия, 450077, г. Уфа, ул. Коммунистическая, 50/2 \\ suleimanov1957@mail.ru \\ (C) Кашапов Урал Абубакирович \\ кандидат исторических наук, учитель географии, \\ Лицей № 2 \\ Россия, 452320, г. Дюртюли, ул. Н. Наджми, 38 \\ ural.Kashapov.2014@mail.ru \\ (C) Касенкин Владимир Анатольевич \\ диакон Кафедрального собора во имя Рождества Пресвятой Богородицы г. Уфы, \\ Уфимская епархия Башкортостанской митрополии РПЦ МП \\ Россия, 450077, г. Уфа, ул. Коммунистическая, 50/2 \\ Kasenkin@inbox.ru
}

Аннотация. В статье рассматривается такое социально-политическое учение, как «христианский социализм», которое по-разному оценивалось современниками. Его основополагающим принципом является устроение всей системы общественноэкономических отношений на подлинно христианских началах — равенстве, братстве и социальной справедливости. Согласно идеям этого учения, решение социальных вопросов, основанных на экономическом фундаменте эгалитаризма, возможно посредством религиозно-нравственного совершенствования человеческой личности, деятельной христианской любви и такими определяющими христианскими ценностями, как вера, справедливость, солидарность, достоинство, единство, нравственность, честность, милосердие, семья, культура, национальные традиции, благо человека, трудолюбие, самоограничение и самопожертвование.

Ключевые слова: религия; вера; церковь; христианство; социализм; социальное христианство; христианский социализм.

\section{Для цитирования}

Сулейманов Т. Ф., Кашапов У. А., Касенкин В. А. Христианский социализм как отражение доктрины социального христианства (Часть I) // Евразийство и мир. 2020. № 2. C. 41-56.

Актуальность темы детерминирована тем, что в России остро стоит проблема модернизации всей системы государственных институтов и общественных отношений - политических, экономических, правовых, нравственных и т. д., которые 
формировались с периода становления новой российской государственности. Переход от социалистической модели государственного устройства и экономики к рыночно-капиталистической - либеральному обществу, сопровождался переходом общенациональной социалистической собственности и колхозно-кооперативной во владение нового класса собственников, которые не стали экономически эффективными, и проводимая экономическая политика в стране не была успешной. И на это совершенно точно указывает известный российский ученый-экономист, профессор кафедры международных финансов МГИМО(У) МИД РФ, председатель РЭОШ (Русское экономическое общество им. С. Ф. Шарапова) В. Ю. Катасонов, отметивший, что можно обозначить новейшую, так называемую экономическую, политику одним словом - геноцид. Слово «экономика», далее пишет он, используется здесь совершенно некорректно, поскольку в России экономики нет. Слово «экономика» в переводе с греческого - это домостроительство, в нашей стране на протяжении более четверти века наблюдается абсолютно противоположный процесс — доморазрушение. Некоторые авторы называют этот процесс хрематистикой — процессом накопления. Но, как указывает исследователь, не следует называть происходящее хрематистикой, так как если где-то процесс накопления и происходит, то уж точно не в нашей стране и уж точно не в интересах граждан России. Правильным будет называть это ограблением - ограблением дома [25].

Аналогичную оценку сложившегося экономического положения дал несколько ранее академик Н. Я. Петраков, указавший следующее. В большинстве случаев новые хозяйственники эффективность применения частной собственности в экономике не доказали. Реформы в Российской Федерации не приблизили, но, наоборот, дальше отодвинули её от принятого среднестатистического мирового стандарта - с 20-30-х на 70-80-е места по уровню и качеству жизни. После того как были захвачены природные ресурсы, ранее находившиеся в собственности государства, страна получила частную. Резко снизилась производительность труда во всех тех отраслях, что были «прихватизированы» - в 2-3 и более раза. Объёмы производства с тех пор не превысили и не превышают показатели советского периода. Нет ни заявленной модернизации, ни внедрения новых технологий, ни использования передовых достижений науки [Цит. по: 45].

Захват государственной собственности новыми владельцами, как известно, происходил в процессе приватизации, частью которой были залоговые аукционы, которые по своим масштабам и последствиям являются беспрецедентной в истории современной мировой цивилизации финансовой аферой. Кстати, эти аукционы - всего лишь часть, хотя и наиболее скандальная в истории российской приватизации, один из множества относительно честных способов изъятия собственности у государства. Продав более 150000 предприятий, государство выручило целых $\$ 9,7$ млрд - примерно столько, сколько после адекватной рыночной оценки в 2004 г. было заплачено за один «Юганскнефтегаз», некогда проданный за $\$ 160$ млн. И при этом отработка де-факто мошеннических схем приватизации была де-юре относительно легитимна. Реализация осуществлялась самими государственными чиновниками, которые во всех сделках являлись заинтересованной стороной со множеством аффилированных лиц [31]. 
Сулейманов Т. Ф., Кашапов У. А., Касенкин В. А. Христианский социализм как отражение доктрины социального христианства (Часть I)

Результатом этой беспрецедентной в истории человечества приватизации стала имущественная и социальная дифференциация и, как следствие,- недопустимо высокий уровень неравенства, при котором, по оценкам аналитиков Credit Suisse Research Institute, 10\% самых богатых россиян контролируют 83\% всего благосостояния в стране. Этот показатель в России выше, чем в США, где на 10\% самых богатых приходится 76\% всего личного благосостояния, а ведь США - это государство с наиболее высокой на сегодня в мире концентрацией материального богатства в его денежном выражении [9].

По данным этой исследовательской структуры, на протяжении десятилетий осуществляющей мониторинг распределения благосостояния во всём мире и внутри различных государств, в России с 1.07.2018 по 1.07.2019 г. произошел резкий скачок количества долларовых миллиардеров. Год назад их было 74, сейчас 110. Количество долларовых миллионеров и вовсе теперь сравнимо с населением крупного города - 246 тыс. вместо 172 тыс. человек год назад [9]. При этом вполне закономерным стал рост числа тех, кто живет ниже установленного правительством прожиточного минимума, т.е. в нищете, ибо роскошь одного класса уравновешивается нищетой другого [55, с. 77]. В общей сложности у 200 богатейших российских предпринимателей в 2018 г. было 485\$ млрд. По сравнению с 2017 г. этот показатель увеличился на 5,4\% (25\$ млрд) [16].

Последние социологические исследования свидетельствуют о том неоспоримом факте, что большинство людей разочаровались в капитализме. Так, по данным Edelman Trust Barometer, 56\% опрошенных в мире считают, что вреда от капитализма больше, чем пользы, а улучшения условий своей жизни в ближайшие 5 лет в развитых странах ожидает всего лишь треть населения. Большинство жителей современного мира утратили веру в преимущества капитализма и боятся того, что западная модель демократии теряет свою эффективность, как следует из отчета авторов в октябре-ноябре 2019 г.

В России, в условиях перехода от социалистической плановой экономики к рыночной — к реинкарнации системы капиталистических отношений, принципиально изменилась базовая система ценностей. И если в рамках социалистической системы основой являлись народное благо и справедливость, то для рыночной экономики таковыми являются успех любой ценой, корысть, нажива [66], культивирование религии денег. И соответственно формула «Ничего личного — только бизнес» как нельзя точно отражает суть и характер деловой коммуникации, а также системы нравственных ценностей между субъектами экономических отношений, которые предопределяют мотивацию и принципы деятельности человека, его смысложизненные ориентиры.

Последствием проводимой социально-политической и социально-экономической политики стало то, что радикально изменилась сущность человека; она оказалась деформирована в результате установления социальных систем, основываемых на эксплуатации. Происходит отчуждение человека по четырем онтологическим аспектам: от процесса труда; продукта труда; других людей; человеческого в себе. В совокупности происходит то, о чем сегодня говорят как о расчеловечивание человека [1]. 
Неоспоримым фактом остается то, что сложившаяся в России «новая» система капиталистических отношений создала и новую систему ценностей, где основой всего является маммонизм, следствием чего стало состояние духа, приведшее к принижению понятий, связанных с духовным миром человека. Капиталистические отношения окончательно заставили человека расстаться с идеей развития равенства, братства и социальной справедливости в обществе.

Обращаясь к системе ценностей, которая характерна для капиталистических отношений, нельзя не привести мнение Виссариона Белинского, в котором выразилось негодование сущностью капиталистов: это люди без патриотизма, без всякой возвышенности в чувствах; ибо они служили Плутусу, а этот бог ревнивее всех других богов и больше их имеет право сказать: кто не за меня, тот против меня [57, c. 376]. Сегодня стало актуальным пророчество преподобного Серафима Вырицкого, который говорил, что наступит время, когда не гонения, а деньги и прелести мира сего отвратят людей от Бога и погибнет куда больше душ, чем во время открытого богоборчества. С одной стороны, будут воздвигать кресты и золотить купола, а с другой - настанет царство лжи и зла [40]. Эти слова актуальны сейчас и становятся тяжким обвинением власть имущим. Существующее социальное неравенство, присущее капитализму, вернуло в дискурсивную повестку обращение к теории социализма, в том числе и христианского. Свидетельством этого стало становление и оформление общественно-политического движения «За новый социализм» во главе с оппозиционным политиком Н. Н. Платошкиным.

Рассматривая взаимосвязь христианства и форм общественного устроения, основополагающих принципов общественных отношений, нельзя не привести мнение русского православно-христианского философа Н. Н. Афанасьева, который, на наш взгляд, достаточно обоснованно указал следующее. Вопрос, по-настоящему волнующий современного человека, - социальный вопрос. Остальные вопросы - религиозные, моральные, научные - проходят мимо него, они не задевают его сущности, являясь как бы своего рода спортом или гигиеной умственной жизни. Социальный же вопрос - вопрос всей жизни, всего существования современного человека. От его решения зависит не только судьба современного человека, но и судьба целого ряда предыдущих поколений, судьба всей современной культуры [41].

Несомненно, что обращение к основным политическим концепциям государственного и общественного устройства, в том числе и концепции христианского социализма, с целью использования на практике наиболее рациональных, выверенных жизнью положений данной доктрины, может способствовать повышению эффективности государственных и общественных институтов в процессе генезиса справедливого общественного устройства, основанного в том числе и на системе христианских нравственных ценностей.

Теория христианского социализма с его положением о консолидации нации на основе православно-христианских ценностей, духовно-нравственного совершенствования личности и общества в целом в современных исторических реалиях российской общественной жизни приобретает особую актуальность.

Основополагающая база теории христианского социализма была заложена в произведениях его теоретиков: Н. А. Бердяева [2], С. Н. Булгакова [4-7], Ф. М. Достоевского [14], В. С. Соловьева [49], В. П. Свенцицкого [48], Г. П. Фе- 
Сулейманов Т. Ф., Кашапов У. А., Касенкин В. А. Христианский социализм как отражение доктрины социального христианства (Часть I)

дотова [59-64], С. Л. Франка [65], В. Ф. Эрна [71]. Несмотря на то, что данной теме посвящено значительное количество научных работ $[3,8,11,12,13,15,17$, $18,21,23,28,29,30,33,34,42,43,44,46,47,50,51,52,53,54,56,65,68,69,70]$, она вновь и вновь приковывает к себе внимание, что, конечно же, детерминировано ее актуальностью.

Мы понимаем, что в рамках данной работы не представляется возможным раскрыть рассматриваемую тему в полном объеме, а потому сосредоточим свое внимание прежде всего на тех аспектах названной темы, которые все еще, на наш взгляд, не получили своего должного освещения в научной литературе, и полагаем, что наша работа в определенной степени несколько дополнит существующие представления о христианском социализме.

Цель данной статьи состоит в том, чтобы рассмотреть основные положения учения русского христианского социализма в сравнении с западноевропейской доктриной социального христианства. Приступая к рассмотрению названной темы, необходимо определиться с понятийным аппаратом исходя из того, что это является исходным пунктом и непременным и обязательным условием для любой научной работы, потому что без категориально-терминологической базы невозможно раскрыть в полной мере тему исследования, в связи с этим приведем суждения известных русских философов - П. А. Флоренского и Э. В. Ильенкова.

Относительно значимости используемой терминологии П. А. Флоренский мудро говорил студентам Московской духовной академии следующее. Суть науки - в построении или, точнее, в устроении терминологии. Всякая наука - система терминов. Поэтому жизнь терминов и есть история науки - все равно какой: естествознания ли, юриспруденции или математики. Изучить историю науки - значит, изучить историю терминологии, т. е. историю овладения умом предлежащего ему предмета знания [Цит. по: 67, с. 388]. Э. В. Ильенков, указывая на роль и значение понятий, которыми оперируют в научном исследовании, вполне обоснованно указывал, что важны ведь не слова, а понятия [20, с. 171$]$.

Цели и задачи данной работы определяются такими ключевыми понятиями, как христианство, социализм, социальное христианство, христианский социализм. В первую очередь мы определимся с понятием «христианство». Отметим, что христианство - это «вероучение, исходящее от Иисуса Христа, и основанные на нем формы организации общественной религиозной жизни». Вышеназванное, конечно же, не отражает всей сущности понятия «христианство», потому мы его дополним тем, что нашло свое отражение в Энциклопедическом словаре Брокгауза и Ефрона, где Б. Мелиоранский и Ф. Зелинский, раскрывая суть христианства, писали о том, что это всемирная религия, первая в настоящее время по числу последователей (около 494 млн) и по культурно-историческому значению своему и принявших ее народов, признающая себя откровением Единого в Троице Истинного Бога, Творца и Промыслителя Вселенной, Спасителя и Освятителя людей.

Следующим понятием является «социализм». Обращаясь к рассмотрению того, что стоит за понятием «социализм», мы должны отметить, что его смысл никогда не был однозначным и в настоящее время существует целое множество его интерпретаций. По достаточно точному замечанию Г. П. Федотова, социализм стал очень спорным, очень запутанным словом. 
В работе не рассматривается весь спектр имеющихся дефиниций «социализм» и приводятся лишь те, что, на наш взгляд, в большей мере отражают его суть. Приведем толкование понятия «социализм» в Энциклопедическом словаре Ф. А. Брокгауза и И. А. Ефрона - статье, подготовленной Н. Кареевым. Согласно его трактовке термин «социализм» был употреблен впервые в 1834 г. в статье Пьера Леру «De lindividualisme et du socialism», напечатанной в «Revue Encyclop é dique». Оно обозначает здесь нечто диаметрально противоположное индивидуализму во всех его проявлениях в моральной и социальной жизни человека.

Современная трактовка слова «социализм» подразумевает его употребление в собственном и несобственном смысле. В собственном смысле слова под социализмом понимается совокупность различных теорий, направленных на кардинальное изменение экономического порядка через уничтожение частной собственности на средства производства и свободной конкуренции. Являясь противоположностью индивидуалистическому началу, социализм ставит целью подчинение частнособственнического интереса общественной пользе через перераспределение производства и общественных благ из сферы частного интереса, поставив на его место общественный контроль. В этом широком смысле под социализмом подразумевается коллективизм; ему дается и еще более широкое значение, когда к коллективистам причисляют и анархистов.

Социализм в основе есть учение антииндивидуалистическое, тогда как анархизм является, наоборот, крайним логическим выводом из индивидуализма. Социализм стремится к общественной организации по возможности всего человечества для ведения производства общими организованными силами, следовательно, по необходимости признает принудительную (государственную) власть $[22$, с. 38]. Н. В. Козловская, осуществив лингвистический анализ словарной статьи «Социализм» в Энциклопедическом словаре Ф. А. Брокгауза и И. А. Ефрона, приходит к выводу, что данный термин имеет еще и такое значение: 1) непрерывность идейного развития; 2) связь теории с жизненной практикой; 3) научное обоснование теории [27].

Обращаясь к сущности значения понятия «социализм», нельзя не привести суждения русских дореволюционных мыслителей. Н. Г. Чернышевский полагал, что сущность социализма имеет отношение к экономической жизни. Экономическим бытом не исчерпываются коренные перемены всей жизни человека. И его отношение к другим людям по кровным или душевным привязанностям, и его воспитание, и его национальные отношения, и т. д. обусловлены экономической жизнью [58, с. 239]. А. И. Герцен в своей работе «Письма из Италии» отмечал, что социализм осуществление идеала национальной экономии. Политическая экономия является вопросом, социализм - его разрешением. Политическая экономия - это наблюдение, описание, статистика, история производства и оборота, обращения богатств. Социализм - это философия, организация и наука [58, с. 123]. А в работе «Порядок торжествует» уточнил следующее - социализм идет навстречу экономической справедливости [57, с. 414].

Известный российский философ С. Л. Франк исходит из православнохристианского подхода к социализму и определяет его как настроение действенной любви к ближним, серьезного чувства ответственности за их материальную судьбу, и потому всякий христианин, поскольку он хочет быть истинным христианином, 
Сулейманов Т. Ф., Кашапов У. А., Касенкин В. А. Христианский социализм как отражение доктрины социального христианства (Часть I)

должен в этом смысле быть социалистом [65, с. 64]. Основатель первого социалистического государства В. И. Ленин определил социализм в своей работе «Грозящая катастрофа и как с ней бороться», в которой дал свое понимание в исключительно экономических категориях, согласно которым социализм есть не что иное, как государственно-капиталистическая монополия [32, с. 192].

Современный исследователь Ю. Шеррер, обращаясь к проблеме понятия «социализм», приходит к тому, что это и совокупность доктрин, и политические движения, которые ставят перед собой цель - осуществить эти доктрины на практике, а также определенная организация общества [36, с. 351]. В своем антибуржуазном смысле термин «социалисты» был впервые употреблен в Англии в 1827 г. для обозначения сторонников кооперативного движения Роберта Оуэна. Во Франции понятие «социализм» появилось в 1832 г. в журнале «Глоб» для того, чтобы охарактеризовать учение Сен-Симона и его последователей.

Ю. Шеррер также отмечает, что идея равенства не является единственной центральной идеей социализма. Более важной является идея сообщества, противопоставляемая индивидуализму, в котором человек может использовать все свои потенциальные возможности и добиться своего полного освобождения [36, с. 352].

В 1869 г., когда в г. Эйзенахе была организована Социал-демократическая рабочая партия (партия Фердинанда Лассаля, которая еще в 1863 г. использовала понятие «социал-демократия»), один из ее основателей - Вильгельм Либкнехт заявил о полном тождестве для него понятий демократический и сочиалистический [36, c. 353].

Наиболее полное понимание понятия «социализм» приводит политический словарь, составленный учеными МГИМО (У) МИД РФ, в котором поясняется, что социализм происходит от лат. «socialis» и означает «общественный», и данное понятие содержит в себе несколько положений: 1) идеал общественного устройства, который лежит в основе многочисленных утопий периода становления капитализма (утопический социализм Т. Кампанеллы, Т. Мора, Ш. Фурье, К. А. Сен-Симона, Р. Оуэна и др.); негативная реакция на частную собственность и индивидуализм, в силу чего социализм выступает оппонентом прежде всего либерализма; 2) оформившаяся в XIX в. политическая идеология с такими ключевыми положениями, как идеал общественной собственности, предполагающий национализацию частной собственности в пользу социалистического государства или совместное акционернокооперативное владение; защита интересов обездоленных путем классовой борьбы; принцип эгалитаризма; упор на общество (класс) и общественные потребности, т.е. коллективизм, и др.; 3) низшая фаза коммунистической общественно-экономической формации в трудах классиков марксизма; 4) нерадикальные (в отличие от коммунистических, национал-социалистических или национал-большевистских) партии и движения, руководствующиеся различными социалистическими или социалдемократическими доктринами и строго придерживающиеся легальной, в том числе через выборы, практики политической борьбы; центральные программные идеи социалистов - политический либерализм (плюрализм, терпимость, демократия и т. д.), многоукладная экономика, социальное государство, экономическая политика в духе Дж. Кейнса, равенство, реализуемое через социальные программы; 5) название 
общественно-экономического строя, основанного на социальных и экономических представлениях К. Маркса и В. И. Ленина, реализованный в СССР и странах «народной демократии», а также национальные модели «государства всеобщего благоденствия»: самый известный вариант - «шведский социализм» [38, с. 590-591].

Сойдемся на том, что это прежде всего политическое учение и течение, ориентированное на создание общества, где экономической основой будет общенародная собственность на орудия и средства производства, на базе которой создается новая система производственных отношений, где труд является обязанностью и делом чести каждого трудоспособного гражданина и источником развития всех физических и духовных способностей человека, целью которого является удовлетворение как общественных, так и индивидуальных потребностей, утверждается социальное равенство и справедливость.

Социалистическое общество - это то, в котором устанавливается власть трудового народа и люди объединяются во имя общих задач и целей, во имя удовлетворения их общественных и личных потребностей и интересов и где высшей целью общественного развития становится человек, где осуществляется подлинный гуманизм общественных отношений, создаются подлинные условия для свободного и всестороннего совершенствования всех членов общества и основным принципом которого является: от каждого по способностям, каждому по труду [37, с. 121].

Рассмотрев суть понятий «христианство» и «социализм», мы перейдем к тому, что стоит за определением «социальное христианство». В Энциклопедическом словаре по религиоведению «социальное христианство» толкуется в паре с понятием «социальное христианское движение», и они означают буквально следующее: общее название ряда течений и школ, возникших и сформировавшихся в XIX в. в западноевропейских странах в рамках религизных доктрин католицизма и протестантизма. Социальное христианство выступало и выступает как религиозное истолкование актуальных социальных проблем на основе христианской теологии, философии, этики и социологии.

Впервые понятие «социальное христианство» появилось во Франции в 20-30-х гг. XIX в. в форме «социального католицизма» - движения, которое выступило с предложением определенных социальных реформ в целях разрешения социальных противоречий. Главными положениями движения, именовавшегося «социальным католицизмом», были следующие. Это осознание факта существования «социального вопроса»; теоретическая разработка условий его решения; конкретные попытки осуществить их на практике в виде создания различных сообществ — католических производственных объединений, кредитных касс и сельскохозяйственных товариществ [35].

3.П. Трофимова, исследуя «социальное христианство», указывает на то, что «социальное христианство (social christianity) - религиозно-политическое учение, проповедующее Царство Божье на земле, возрождение раннехристианских идеалов любви и справедливости. Сам термин «социальное христианство» был введён протестантским теологом Вашингтоном Глэденом, ранним «апостолом» социального евангелизма, автором труда «Рабочие и работодатели» [56, с. 3]. 3. П. Трофимова уточняет, что понятия «социальное христианство», «христианский социализм» (christian socialism), «социальное евангелие» (social gospel) употребляются ею как 
Сулейманов Т. Ф., Кашапов У. А., Касенкин В. А. Христианский социализм как отражение доктрины социального христианства (Часть I)

синонимы, поскольку именно так в своих трудах их используют сами представители данного течения, наиболее авторитетными деятелями которого являются В. Глэден, В. Раушенбуш, Л. Эббот, Д. Р. Глисс, Ф. Пибоди, Ш. Матьюс, Д. Шарп, И. Стронг, Дж. Домбровски, А. Эбел, Р. Елей и другие [56, с. 3].

Социальное христианство в узком смысле понимается как культурноисторическое движение, которое начало распространяться во второй половине XIX в., в основном в среде протестантского духовенства США и Европы [70, с. 3], а в широком смысле данное течение охватывает не только религиозные круги, но и практически все слои населения [56, с. 3]. Характеризуя социальное христианство и ссылаясь на работу европейского исследователя П. А. Картера «The Decline and Revival of the Social Gospel», она указывает на тот аспект данных доктрин, что они направлены не столько на изменение общества, сколько на самореализацию человека и нахождение для этого экономических, политических и культурных средств [56, с. 11]. Стратегия социального христианства, как отмечает исследователь, это стратегия самоспасения. Но это и социальное спасение. Социальный идеал рассматривается как продукт человеческой независимости... Бог в этой теории является средством для достижения этого идеала [Цит. по: 56, с. 11].

Социальное христианство по-разному оценивалось его современниками. Так, одни (Дж. Беннет, В. Глэден и другие) считали его оптимистической теорией, направленной на изменение и реформирование общества на основе христианских принципов. Другие, в основном неортодоксы и, в частности, Р. Нибур, считали его утопическим социализмом. Отметим, что многие представители данного движения были связаны с социалистическим, демократическим, рабочим движениями и их программами. Идеи социального христианства актуальны и в современной либеральной философии, и социальной жизни США и Европы [56, с. 11].

Н. Сомин определяет «социальное христианство» как движение в христианстве, стремящееся улучшить быт, образование и вообще жизнь рабочих без изменения социального строя, в том числе без уничтожения господства частной собственности [50]. Аналогичную позицию в трактовке данного понятия занимает и С. А. Кибальник, который считает, что, используя понятие «социальное христианство», делается акцент не на обобществлении собственности, а на постепенном духовном развитии общества - одном из основополагающих принципов данного течения [26, с. 71].

Приведенные нами дефиниции социального христианства позволяют утверждать, что понятие появилось в западноевропейской мысли, но М. А. Карташев поясняет, что его ввел в научный оборот В. В. Зеньковский в своей работе «История русской философии» для характеристики социально-политических взглядов М. М. Сперанского. Он констатирует определенную идейную близость между «социальным христианством» и «христианским социализмом», направлением общественной мысли, возникшим в 30-40-х гг. ХІХ в. в Западной Европе [24, с. 6].

И, наконец, рассмотрим суть понятия «христианский социализм». В первую очередь обратимся к его толкованию в Энциклопедическом словаре Ф. А. Брокгауза и И. А. Ефрона, где оно определяется как учение, признающее существование социального зла в современном общественном строе и стремящееся исправить его при помощи подъема религиозно-нравственных начал в различных слоях народа, 
не выходя из рамки нынешних государственных форм и сохраняя господство частной собственности [10, с. 633]. Аналогичное толкование христианского социализма мы видим во II томе Полного православного богословско-энциклопедического словаря, 1913 года издания, где указывается, что христианский социализм - учение, которое стремится исправить существующее в мире социальное зло и неравенство посредством подъема религиозно-нравственных начал в народе, не выходя из рамок современных государственных форм и сохраняя господство частной собственности.

Имеется много видов и разновидностей этого учения. Иногда христианский социализм идет очень далеко навстречу революционному социализму во всех требованиях, предъявляемых современному государству, отказываясь идти за ним в его конечных стремлениях; таков был христианский социализм в Англии, ныне в Бельгии. Наоборот, иногда христианский социализм выступает против революционного, доказывая, что требования социализма заключаются уже в Евангелии (братство, равенство, помощь бедным) и не противоречат основам семьи, религии и государства.

По преимуществу христианский социализм подчеркивает религиозные основания своего учения; нередко он даже вырождается в антисемитизм. Таким он является в своем главном течении в Германии и особенно в Австрии. Впервые христианский социализм появился во Франции. Сообразно с тем, появляется ли христианский социализм в среде католиков или протестантов, он принимает форму католического социализма или евангелического. У нас в России партии такой нет, изредка встречаются отдельные представители и последователи этого западного течения ${ }^{1}$.

В Советской исторической энциклопедии дается следующее толкование. Христианский социализм - система идей и религиозно-политические течения, сторонники которых утверждают, что социалистические идеалы - равенство всех людей, братство, обязательный труд, гуманизм - неразрывно связаны с христианством (являющимся будто бы их первоисточником) и что христианская церковь - лучший защитник интересов трудящихся (аналогичные представления о религии как источнике гуманизма и социальной справедливости пропагандируют и некоторые представители нехристианских религий).

Христианский социализм отвергает, в противовес научному социализму, революционную классовую борьбу пролетариата, а для решения коренных проблем современности рекомендует нравственное самосовершенствование, христианскую любовь и сотрудничество классов. Христианский социализм возник в 1-й пол. XIX в. сначала как разновидность феод. социализма. Проповедниками X. с. выступили католический священник Ф. Р. Ламенне во Франции, англиканские священники Ф. Д. Морис и Ч. Кингсли в Англии, представители церковных кругов в других странах.

Идеализируя феодальное прошлое и критикуя, часто довольно резко, современное им буржуазное общество, обрекающее на страдания народные массы, они усматривали причину общественных бедствий в «испорченности человеческой натуры» и в отходе от религии. Элементы христианского социализма содержались и во взглядах некоторых социалистов-утопистов (Э. Кабе, В. Вейтлинг и др.), обосновывавших идеи коммунизма ссылками на книги Нового завета и практику первоначального христианства.

\footnotetext{
${ }^{1}$ Полный православный богословский энциклопедический словарь. М.: Изд-во П. П. Сойкина, 1913. Т. 2. С. 587 (стлб.2297-2290).
} 
Сулейманов Т. Ф., Кашапов У. А., Касенкин В. А. Христианский социализм как отражение доктрины социального христианства (Часть I)

Большое влияние на развитие христианского социализма, принявшего со 2-й пол. XIX в. буржуазный характер, оказал майнцский епископ барон фон Кеттелер (был посвящен в епископы в 1850 г.), сформулировавший основы социальной программы католической церкви, направленной на борьбу с социалистическим движением. В отличие от феодального, сторонники которого апеллировали к «совести» и «человеколюбию» господствующих классов, христианские социалисты перенесли теперь пропаганду в народные массы с целью вовлечения их в подконтрольные церкви организации (профсоюзы, культурные общества, политические партии и др.), проповедовавшие классовое сотрудничество и вражду к научному социализму ${ }^{1}$.

В современном энциклопедическом словаре по политологии христианский социализм определен как многочисленные течения в современном христианстве, обосновывающие социалистическую идеологию и практику положениями евангельского учения [39, с. 388].

В части, касающейся понимания христианского социализма в зарубежной справочной научной литературе, обратимся к классической Оксфордской энциклопедии. Христианский социализм (Christian Socialism), как указывается в нем, широко распространенное название одной из форм социализма, основанного на идеалах христианского протестантизма. Термин впервые появился в Англии в 1840-х гг. среди священнослужителей (одним из которых был Чарлз Кингли), стремившихся улучшить положение трудящихся и осуждавших социальные последствия конкуренции в бизнесе и неограниченный индивидуализм. В 1889 г. были основаны Христианский социальный союз в Англии и Общество христианских социалистов в США. Однако эти церкви больше заботились об интересах капитала, чем о положении трудящихся, что привело к возникновению более радикального движения «Социальное Евангелие». Его лидеры, главным образом американцы, старались отыскать связь этого учения с современными социальными и экономическими проблемами ${ }^{2}$.

Православный публицист и философ игумен Вениамин (Новик) в работе «Христианский социализм прот. Сергия Булгакова» приходит к тому, что христианский социализм, по сути, есть христиански осмысленная социальная этика [19]. Н. В. Сомин в своей работе «Христианский социализм как русская идея» высказывает мысль о том, что христианский социализм - это особый общественный строй, идеология которого основана на христианских ценностях (в России - на православии), а экономический уклад - на социалистических принципах [50]. В. А. Толстиков определяет христианский социализм как мировоззрение, в котором христианские идеалы окрашиваются духовным содержанием, где ликвидация эксплуатации и резких социальных контрастов является движением к христианскому общественному идеалу - всеединству, то есть соборности, и его сутью является отрицание классовой психологии, раскалывающей общество [52, с. 99].

Из приведенных нами дефиниций христианского социализма следует, что это понятие не имеет единого, общепринятого определения в силу того, что оно достаточно сложно и многопланово, является исключительно многомерным социальноисторическим явлением.

\footnotetext{
${ }^{1}$ Христианский социализм // Советская историческая энциклопедия [Электронный реcypc]. URL: /dic.academic.ru /dic.nsf/sie /19505 (дата обращения: 12.10.2020).

2 Оксфордская иллюстрированная энциклопедия [Электронный ресурc]. URL: www. xn-80aacc4bir7b.xn (дата обращения: 12.10.2020).
} 
В своей работе возьмем за основу определение С. С. Иванова. В своем исследовании этот социально-политический феномен он определил как совокупность религиозно-общественных и социально-политических течений, в которых правомерность социалистической программы обосновывается ссылками на положения христианского вероучения и непреходящие ценности христианской культуры при условии подчинения социализма христианству в их органичном синтезе $[18$, с. 16$]$.

Отмечая несомненную связь социального христианства и христианского социализма как идеологических концепций, мы должны констатировать, что она заключается в том, что в них ключевым элементом является христианская нравственность, пронизывающая всю систему общественных отношений и предусматривающая «равнение на Христа», а также «христианский идеал братства между людьми независимо от их сословной принадлежности [26, с. 70].

Рассмотрев основные подходы к определению сущности христианского социализма, мы укажем на генезис теории христианского социализма, при этом не будем достаточно подробно освещать историю становления концепции христианского социализма в России, что обусловлено форматом данной работы.

Кратко рассматривая эволюцию концепции христианского социализма, отметим, что, согласно исследованию С. С. Иванова, христианский социализм в своем развитии прошел следующие этапы: формирование ранней христианской общины; деятельность еретических народных движений и сект; появление философских учений христианских социалистов; развитие христианского социализма в рамках социальной доктрины Церкви; организация и функционирование христианско-социалистических партий и общественных объединений классического типа; зарождение и развитие христианскосоциалистических движений и групп персоналистической ориентации [18, с. 18].

И результатом данного социально-исторического развития этого течения явилось формирование основных направлений христианской персоналистической политики, нацеленной на создание условий для всесторонней, гармоничной, творческой самореализации человека в гражданском обществе [18, с. 18].

Продолжение следует.

\section{Литература}

1. Багдасарян В. Э. Аксиология марксизма в контексте мировых исторических трендов [Электронный pecypc]. URL:/rusrand.ru/docconf/aksiologiya-marksizma-v-kontekste-mirovyh istoricheskih-trendov (дата обращения: 20.10.2020).

2. Бердяев Н. А. Философия неравенства / сост. и отв. ред. О. А. Платонов. М.: Изд-во Ин-та русской цивилизации, 2012. 624 с.

3. Булатова М. Н. Христианские ценности как предпосылка либерального общества // Сибирский юридический вестник. 2005. № 1. С. 3-7.

4. Булгаков С. Н. Труды по социологии и теологии: в 2 т. Т. 1: От марксизма к идеализму. М.: Наука, 1997. 336 с.

5. Булгаков С. Н. Труды по социологии и теологии: в 2 т. Т. 2: Статьи и работы разных лет. 1902-1942. М.: Наука, 1997. 828 с.

6. Булгаков С. Н. Два града: исследование о природе общественных идеалов: [в 2 т.]. М.: Путь [т-во тип. А. И. Мамонтова], 1911. Т. 1. 303 с.

7. Булгаков С. Н. Два града: исследование о природе общественных идеалов: [в 2 т.]. М.: Путь [т-во тип. А. И. Мамонтова], 1911. Т. 2. 313 с. 
Сулейманов Т. Ф., Кашапов У. А., Касенкин В. А. Христианский социализм как отражение доктрины социального христианства (Часть I)

8. Буренков А. Русская христианская философия и христианский социализм - национальная идеология новой России [Электронный ресурс]. URL: www.gr-sozidatel.ru/articles/ burenkov-russkaya-hristianskaya-filosofiya-i-hristianskij-socializm-nacionalnaya-ideologiya-novojrossii.html (дата обращения: 12.10.2020).

9. Василиев В. В РФ всё-таки повальная бедность или повальная нищета? [Электронный ресурс]. URL: newsland.com/user/4297738632/content/v-rf-vsio-taki-povalnaia-bednostili-povalnaia-nishcheta/6910276 (дата обращения: 12.10.2020).

10. Водовозов В. Христианский социализм // Энциклопедический словарь. Т. XXXVII-А. Ходский - Цензура. Издатели Ф. А. Брокгауз (Лейпциг), И. А. Ефрон (С.-Петербург). СПб.: Издательское дело, Брокгауз-Ефрон, 1908. С. 633-635.

11. Воронцова И. В. «Социальное христианство» С. Н. Булгакова, Христианского братства борьбы и Н. Н. Неплюева (1905-1908) // Вестник ПСТГУ. Сер. 2. История. История Русской православной церкви. 2015. Вып. 3(64). С. 18-30.

12. Воронцова И. В. «Социальное христианство» (С. Н. Булгаков и Христианское братство борьбы) в контексте религиозного движения в России начала XX века // Религиоведение. 2015. № 4. С. 14-20.

13. Гринберг Р. С. Ситуация с расслоением общества близка к критической // Новые известия. 2020. 20 янв. [Электронный ресурс]. URL: newizv.ru /article/general/20-01-2020/ ruslan-grinberg-situatsiya-s-rassloeniem obschestva-blizka-k-kriticheskoy (дата обращения: 12.10.2020).

14. Достоевский Ф. М. Дневник писателя.1877-1880-1881 (IV январский выпуск 1881 г.) [Электронный ресурс]. URL: azbyka.ru/fiction/dnevnik-pisatelya-1877-1880-1881/ (дата обращения: 12.10.2020).

15. Зельцер В. З. Христианский социализм на Западе (историч. очерк) / Центр. совет Союза воинствующих безбожников СССР. М.: Безбожник, 1930. 78 с.

16. Иванов Д. Насколько в России сильна пропасть между бедными и богатыми? Цифры и причины социального неравенства // Reconomica. 2019.19 окт. [Электронный ресурc].URL: yakutiafuture.ru/2019/12/25/naskolko-v-rossii-silna-propast-mezhdu-bednymi-i-bogatymi-cifryi-prichiny-socialnogo-neravenstva (дата обращения: 12.10.2020).

17. Иванов С. С. Христианский социализм как политический феномен: опыт России и Европы / под ред. А. И. Демидова. Саратов: Изд-во СГСЭУ, 2009. 255 с.

18. Иванов С. С. Христианский социализм как политический феномен: автореф. дис. ... Д-ра полит. наук. Саратов, 2011. 42 с.

19. Игумен Вениамин (Новик). Христианский социализм прот. Сергия Булгакова [Электронный ресурс]. URL: www.vehi.net/bulgakov/novik.html (дата обращения: 12.10.2020).

20. Ильенков Э. В. Философия и культура. М.: Политиздат, 1991. 464 с.

21. Кара-Мурза А. А. На пути к христианскому либерализму: эволюция концепции «свободы» в трудах Г. П. Федотова // Политическая концептология. 2015. № 1.С. 187-208.

22. Кареев Н. Социализм // Энциклопедический словарь. Т. ХХХІ. София-Статика. Издатели Ф.А. Брокгауз (Лейпциг), И. А. Ефрон (С.-Петербург). СПб.: Издательское дело, Брокгауз-Ефрон, 1900 [Электронный ресурс]. URL: tolkslovar.ru/s10228.html (дата обращения: 12.10.2020).

23. Карсавин Л. П. Церковь, личность и государство // Малые сочинения. СПб.: Алетейя, 1994. 532 с.

24. Карташов М. А. Концепция «социального христианства» в политической философии М. М. Сперанского: дис. ... канд. филос. наук. М., 2006.118 с.

25. Катасонов В. Ю. Правительство готовит пакет непопулярных мер; каких конкретно - пока секрет [Электронный ресурс]. URL: ruskline.ru/opp/2018/iyun/8/pravitelstvo_ gotovit_paket_nepopulyarnyh_mer_kakih_konkretno_poka_sekret/ (дата обращения: 12.10.2020). 
26. Кибальник С. А.«Христианский социализм» или «Социальное христианство»? (Гоголь и Достоевский в истории русской социально-философской мысли) // Проблемы исторической поэтики. 2017. Т. 15, № 3. С. 70-90.

27. Козловская Н. В. Термин «социализм» в русском религиозно-философском дискурсе [Электронный ресурс] // Политическая лингвистика. 2012. № 4(42). С. 124-129. URL: www. philology.ru/linguistics2/kozlovskaya-12.htm (дата обращения: 12.10.2020).

28. Костерин А. Дух, душа и тело православного социализма // Православный социализм как русская идея [Электронный ресурc]. URL: chri-soc.narod.ru/kos_Dukh_dusha_i_telo_PS.htm. (дата обращения: 12.10.2020).

29. Курбенков В. А., Кулажников В. В. Христианство и социализм в конце XIX - начале XX в. в контексте критики социалистической идеологии // Наука и современность. Сер. Юридические науки. Политология. 2014. № 1(1). С. 52-59.

30. Лавров П. Л. Статьи. Встань, человек! [Электронный ресурс] / сост., подготовка текстов, примеч. А. И. Володина, Б. М. Шахматова. М.: Советская Россия, 1986 (Худож. и публицист. б-ка атеиста). URL: az.lib.ru/l/lawrow_p_1/text_0060.shtml (дата обращения: 12.10.2020).

31. Лебедев А. «Первородный грех» российского капитализма: как избавиться от проклятия? Британский опыт // Новая газета. 2020. № 8. 27 янв.

32. Ленин В. И. Грозящая катастрофа и как с ней бороться // ПСС. Т. 34. С. 155-199.

33. Мелиоранский Б., Зелинский Ф. Христианство // Энциклопедический словарь. T. XXXVII-A. Ходковский — Цензура. Издатели Ф. А. Брокгауз (Лейпциг), И. А. Ефрон (С.-Петербург). СПб.: Издательское дело, Брокгауз-Ефрон, 1908. № 6. С. 635-679.

34. Молотков А. Е. Миссия России. Православие и социализм в XXI веке. СПб.: Русский остров, 2008. 399 с.

35. Овсиенко Ф. Г. Социальное христианство [Электронный ресурс] // Религиоведение. Энциклопедический словарь / под ред. А. П. Забияко, А.Н. Красникова, Е. С. Элбакян. М.: Академический проект, 2006. 1256 c. URL: religa.narod.ru/zabijako/s17.htm (дата обращения: 12.10.2020).

36.50/50: опыт словаря нового политического мышления / под общ. ред. М. Ферро и Ю. Афанасьева. М.: Прогресс, 1989. 560 с.

37. Очерк теории социализма / Г. Л. Смирнов [и др.]. М.: Политиздат, 1989. 463 с.

38. Политология: учебник / А. Ю. Мельвиль [и др.]. М.: Изд-во Моск. гос. ин-та междунар. отношений, 2011. 624 с.

39. Политология: энциклопедический словарь / под общ. ред. и сост. Ю. И. Аверьянов. М.: Изд-во Моск. коммерч. ун-та, 1993. 431 с.

40. Преподобный Серафим Вырицкий. Пророчества [Электронный ресурс]. URL: azbyka.ru/znakomstva/blogs/0/185405 (дата обращения: 12.10.2020).

41. Протопресвитер Афанасьев Н. Н. Христианство и социальный вопрос. Речь на Актовом собрании Православного богословского института в Париже 28.03.1965 г. [Электронный ресурс] // Азбука веры: православная энциклопедия. URL: azbyka.ru/otechnik/Nikolaj_Afanasev/ hristianstvo-i-sotsialnyj-vopros (дата обращения: 12.10.2020).

42. Священномученик Иоанн Восторгов. Христианство и социализм. Публичные чтения в Историческом музее в г. Москве в 1906 г. [Электронный pecypc]. URL: antimodern.ru/ social (дата обращения: 12.10.2020).

43. Священномученик Иоанн Восторгов. Социализм при свете христианства [Электронный ресурс] // Полное собрание сочинений. T. 5. URL: /otechnik /Ioann Vostorgov/polnoesobranie-sochinenij-tom-5 (дата обращения: 12.10.2020).

44. Священномученик Иларион (Троицкий), архиепископ Верейский. Христианство и социализм. На современные темы [Электронный ресурс] // Азбука веры: православная эн- 
Сулейманов Т. Ф., Кашапов У. А., Касенкин В. А. Христианский социализм как отражение доктрины социального христианства (Часть I)

циклопедия. URL: azbyka.ru/otechnik/Ilarion_Troitskij/khristianstvo-i-sotsializm-na-sovremennyetemy (дата обращения: 12.10.2020).

45. Симонян Р. Х. Что принесли России реформы 1990-х годов? Экономические итоги- I [Электронный ресурс]. URL: rusrand.ru /forecast /chto-prinesli-rossii-reformy-1990-hgodov — ekonomicheskie-itogi - I (дата обращения: 12.10.2020).

46. Сидоров В. П. Христианский социализм в России в конце XIX - начале XX в.: филос.-религиовед. очерк / Рос. гос. пед. ун-т им. А. И. Герцена, Череповец. гос. пед. ин-т им. А. В. Луначарского. Череповец: Изд-во Череповец. гос. пед. ин-та, 1995. 164 с.

47. Сизова Н. Е. Концепция «христианского социализма» как модель общественного идеала у С. Н. Булгакова // Вестник Томского государственного университета. 2015. № 400. C. $100-103$.

48. Собрание сочинений протоиерея Валентина Свенцицкого: в 2 т. М.: Даръ. 1552 с.

49. Соловьев В. С. Оправдание добра: нравственная философия / вступ. ст. А. Н. Голубева и Л. В. Коноваловой. М.: Республика, 1996. 479 с.

50. Сомин Н. Православный социализм как русская идея [Электронный ресурс] // Сборник статей. М., 2015. 544 c. URL: chri-soc.narod.ru/somin_kniga_p_s_kak_russaya_idea. htm (дата обращения: 12.10.2020).

51. Сомин Н. В. Христианский социализм как русская идея [Электронный ресурс]. URL: chri-soc.narod.ru/chs_kak_russkaja_idea.htm (дата обращения: 12.10.2020).

52. Толстиков В. А. Христианский социализм как мировоззренческий фактор развития гражданского общества // Наука. Искусство. Культура. 2015. Вып. 4(8). С. 88-101.

53. Толстиков В. А. Христианский социализм как вариант социально-экономического развития России // Казанская наука. 2015. № 4. С. 114-116.

54. Толстиков В. А. Идея справедливого общественного устройства в русской религиозной и философской мысли до Октябрьской революции // Научные ведомости. Сер. Философия. Социология. Право. 2016. Вып. 38, № 24(245). С. 186-191.

55. Торо Генри Дэвид. Высшие законы: пер. с англ. / под общ. ред., предисл., сост. Н. Е. Покровского. М.: Республика, 2001. 412 с.

56. Трофимова 3. П. Социальное христианство в США середины XIX - начала ХХ в. // Религиоведение. 2015. № 4. С. 3-13.

57. Утопический социализм: хрестоматия / под общ. ред. А. И. Володина. М.: Политиздат, 1982. 512 с.

58. Утопический социализм в России: хрестоматия / А. И. Володин, Б. М. Шахматов; под общ. ред. А. Н. Володина. М.: Политиздат, 1985. 590 с.

59. Федотов Г. П. Судьба и грехи России: избранные статьи по философии русской истории и культуры: в 2 т. / сост. В. Ф. Бойкова. СПб.: София, 1991. Т. 1. 350 с.

60. Федотов Г. П. Судьба и грехи России: избранные статьи по философии русской истории и культуре: в 2 т. / сост. В. Ф. Бойков. СПб.: София, 1992. Т. 2. 348 с.

61. Федотов Г. П. Письма о социализме [Электронный ресурс] // Христианин в революции: сб. ст. Париж, 1957. С. 67-73. URL: www.odinblago.ru/pisma_o_socializme (дата обращения: 12.10.2020).

62. Федотов Г. П. Социальное значение христианства // О святости, интеллигенции и большевизме. Избранные статьи. СПб.: Изд. С.-Петерб. ун-та, 1994. С. 51-78.

63. Федотов Г. П. Основы христианской демократии [Электронный ресурс]. URL: azbyka. ru/otechnik/Georgij_Fedotov/osnovy-hristianskoj-demokratii (дата обращения: 12.10.2020).

64. Федотов Г. П. Что такое социализм [Электронный ресурс] // Азбука веры: православная энциклопедия. URL: //azbyka.ru/otechnik /Georgij_Fedotov/chto-takoe-sotsializm (дата обращения: 12.10.2020).

65. Франк С. Л. Проблема христианского социализма // По ту сторону правого и левого: сб. ст. / под ред. В. С. Франка. Париж: YMCA-PRESS, 1972. С. 62-81. 
66. Хазин М. Воспоминания о будущем. Идеи современной экономики. М.: РиполКлассик, 2019. 463 с.

67. Халипов В. Ф. Наука о власти. Кратология: учеб. пособие. М.: ОСь-89, 2002. 448 с.

68. Христианство: словарь / под общ. ред. Л. Н. Митрохина [и др.]. М.: Республика, 1994. 559 с.

69. Шейнман М. М. Христианский социализм: история и идеология. М.: Наука, 1969. $314 \mathrm{c}$.

70. Шеррер Ю. В поисках "христианского социализма" в России [Электронный ресурс] // Вопросы философии. 2000. № 12. C. 88-135. URL: /az.lib.ru/s /swencickij_w_p/ text_0400_sherrer.shtml (дата обращения: 12.10.2020).

71. Эрн В. Ф. Христианский идеал экономики / сост. и отв. ред. О. А. Платонов // Экономика русской цивилизации. М.: Изд-во Ин-та русской цивилизации, 2008. С. 460-471.

\section{CHRISTIAN SOCIALISM AS A REFLECTION \\ OF THE SOCIAL GOSPEL MOVEMENT (Part 1)}

\section{Timur F. Suleymanov}

Cand. Sci. (Philos.), A/Prof.,

Head of Department of Canonization and Perpetuation

of the Memory of New Martyrs and Confessors,

Ufa Diocese, Bashkortostan Mitropolis, the Moscow Patriarchate

of the Russian Orthodox Church

\section{Ural A. Kashapov}

Cand. Sci. (Hist.),

Geography Teacher

Lyceum No. 2, Dyurtyuli

\section{Vladimir A. Kasenkin}

Deacon of the Cathedral of the Nativity of the Blessed Virgin Mary in Ufa,

Ufa Diocese, Bashkortostan Mitropolis, the Moscow Patriarchate

of the Russian Orthodox Church

50/2 Kommunisticheskaya St., Ufa 450077, Russia

Abstract. The article deals with such a socio-political doctrine as "Christian socialism", which was assessed in different ways by the contemporaries. Its fundamental principle is the organization of the entire system of social and economic relations on a truly Christian basis - equality, fraternity and social justice. According to the ideas of this teaching, the solution to social problems based on the economic foundation of egalitarianism is possible through the religious and moral improvement of the person, active Christian love and such Christian values as faith, justice, solidarity, dignity, unity, morality, honesty, mercy, family, culture, national traditions, human welfare, hard work, self-containment and self-sacrifice. Keywords: religion; faith; church; Christianity; socialism; social gospel; Christian socialism.

Статья поступила в редакцию 01.10.2020; одобрена после рецензирования 30.10.2020; принята к публикации 11.12.2020. 